\title{
IS THERE REALLY A FOREIGN OWNERSHIP WAGE PREMIUM? EVIDENCE FROM MATCHED EMPLOYER- EMPLOYEE DATA
}

\author{
by
}

Fredrik Heyman

Fredrik Sjöholm

Patrik Gustavsson Tingvall

Working Paper 206

November 2004

Postal address: P.O. Box 6501, S-113 83 Stockholm, Sweden. Office address: Sveavägen 65 Telephone: +4687369360 Telefax: +468313017 E-mail: japan@hhs.se Internet:

http://www.hhs.se/eijs 


\title{
Is There Really a Foreign Ownership Wage Premium? Evidence from
}

\author{
Matched Employer-Employee Data
}

\author{
Fredrik Heyman $^{* *}$ \\ Fredrik Sjöholm* \\ Patrik Gustavsson Tingvall*
}

\begin{abstract}
Numerous studies based on firm-level data have reported higher average wages in foreign-owned firms than in domestically-owned firms. This, however, does not necessarily imply that the individual worker's wage increase with foreign ownership. Using detailed matched employer-employee data, we examine the effect of foreign ownership on individual wages, controlling for individual and firm heterogeneity as well as for possible selection bias in foreign acquisitions. We distinguish between foreign greenfields and takeovers and compare foreign ownership with both domestic multinationals and local firms. Our results indicate that employees in foreign-owned firms do not have systematically higher wages than comparable workers in similar Swedish owned firms.
\end{abstract}

JEL: F23, J31, C23

Keywords: FDI, Foreign ownership, Wages, Matched Employer-Employee data, Propensity score matching.

\footnotetext{
Acknowledgements: We are grateful for comments from Pär Hansson, Lena Nekby, Peter Skogman Thoursie, and seminar participants at the ETSG 2004 conference in Nottingham, FIEF, Stockholm University and Stockholm School of Economics. Patrik Gustavsson Tingvall gratefully acknowledges financial support from Tom Hedelius Research foundation.

* Stockholm School of Economics, patrik.gustavsson@hhs.se and Fredrik.sjoholm@hhs.se, ** Trade Union Institute for Economic Research (FIEF), fredrik.heyman@fief.se. Corresponding author: Patrik Gustavsson Tingvall, Stockholm School of Economics, Box 6501, SE 113 83, Sweden.
} 


\section{Introduction}

Foreign direct investment (FDI) has increased dramatically during the last decades and has arguably benefited both host and home countries. The former group of countries may for instance benefit through inflows of new technology and access to foreign markets. An additional benefit could be a positive effect on host country wages. It is well established that foreign owned firms pay higher average wages than domestically owned firms. ${ }^{1}$ Part of this wage premium is caused by foreign firms locating in high wage sectors and localities, but the premium exists even within industries and regions and after controlling for firm characteristics and the average educational level of the labor force. There are several suggestions why foreign firms would pay higher wages than domestic firms. For instance, foreign firms might try to prevent technological spillovers through labor turnover by paying a wage premium (Fosfuri et al., 2001); the wage premium might be caused by rent-sharing arrangements among foreign firms (Budd et al., 2002); by a higher labor demand volatility in foreign plants (Fabri et al., 2003); or as compensation for a higher foreign closure rate (Bernard and Sjöholm, 2003).

However, although the average wage is relatively high in foreign owned firms, it is still unclear if foreign firms pay higher wages for identical workers. Employees differ in many respects such as age, education, gender and previous work experience, all of which have an impact on wages. It is plausible that the foreign wage premium is caused by such characteristics rather than by ownership of the firm. To examine if foreign firms pay a relatively high wage for a given quality of employees calls for a change in the unit of observation: from the firm or plant level to the individual

\footnotetext{
${ }^{1}$ See e.g. Aitken et al (1996), Doms and Jensen (1998), Conyon et al. (2002), Griffith (1999), Girma et al. (2001), Driffield and Girma (2002), Görg et al (2002), Haddad and Harrison, 1993), Lipsey (1994) and Lipsey and Sjöholm $(2002,2004)$. The wage differentials between domestically- and foreign-
} 
worker. In addition, detailed information on worker characteristics is necessary to control for differences in human capital. Such an analysis has previously been constrained by a scarcity of data combining information on individual employees with information on their employers. A recent study by Martins (2004), using matched employer-employee data, finds no effect on individual wages after foreign acquisition of Portuguese manufacturing firms. ${ }^{2}$

This paper combines data on all Swedish firms spanning the period 1990-2000 with a very large sample of more than 2 million Swedish employees covering the period 1996-2000. We contribute to the literature in several respects. First, our matched employer-employee data enables us to analyze the impact of foreign ownership on individual wages, controlling for both firm- and individual heterogeneity. In order to control for unobservable firm and individual characteristics as well as possible selection bias in foreign acquisitions, we combine matching techniques with the more general difference in difference estimator. Second, foreign owned firms might enter the market by a greenfield investment or through an acquisition of a Swedish owned firm. These two modes of entry might have different effects on wages. We therefore compare foreign greenfield investments with foreign acquisitions. Third, to isolate the impact of being a multinational firm we compare foreign owned firms with both Swedish multinational firms and Swedish local firms.

Firm level regressions show, in accordance with the previous literature, that foreign owned firms pay higher wages than domestically owned firms. This wage premium is primarily due to differences between foreign owned firms and Swedish local firms, suggesting that multinationality, as such, is what matters. Comparing 
greenfields with foreign takeovers indicates that greenfields tend to pay the highest wage premium. This is probably driven by the fact that greenfield firms must pay a wage premium in order to attract new workers to their firm.

The estimated wage premium in foreign owned firms is substantially reduced as we change from firm- to individual level estimations. Estimating individual wage equations yields a coefficient for foreign ownership that is close to zero. Finally, results from difference-in-differences estimations show that the individual worker wage level is 2-6 percent higher in acquired than in similar non-acquired firms, but that the wage growth is lower in acquired firms. This result is verified further by fixed-effect estimations suggesting a slightly negative impact on individual wages of foreign takeovers of Swedish firms.

The paper is organized as follows. The following section describes the data and provides descriptive statistics. The empirical methodology is presented in Section III. The results are presented in Section IV. Finally, Section V concludes.

\section{Data Sources and Description}

Data

The analysis is based on three register-based data sets from Statistics Sweden collected by the Trade Union Institute for Economic Research (FIEF). First, for the period 1996-2000 the financial statistics (FS) contain detailed information on all Swedish firms. For the period 1990-1995 we have data on all manufacturing firms with at least 20 employees and non-manufacturing firms with at least 50 employees. ${ }^{3}$

\footnotetext{
${ }^{2}$ Two other studies that uses matched employer-employee data are Bora and Wooden (1998) and Ono and Odaki (2004) who in cross-section studies find individual wages to be relatively high in foreignowned firms in Australia and Japan, respectively

${ }^{3}$ For non-manufacturing firms with less than 50 employees we have a stratified random sample.
} 
Examples of variables included are value added, capital stock (book value), number of employees, total wages, ownership, profits, and industry sector. A detailed description of the variables is found in Tables A1 and A2 in the appendix.

Second, the Regional labor market statistics (RAMS) includes data on all establishments spanning the period 1990-2000. RAMS add information on the composition of the labor force with respect to educational level and demographics.

Finally, the individual wage statistics database (LS) contains detailed information from official registers on a very large representative sample of employed individuals. The LS spans the period 1996-2000 and has approximately 2 million observations per year, which is roughly 50 percent of the Swedish labor force. Examples of variables included are full-time equivalent wages, education, labor market experience, gender and type of job.

The data sets are matched by unique identification codes. The nature of the data sets implies that the firm-level estimations will be based on data for 1990-2000, while the individual-level analysis is based on our matched employer-employee data set for the period 1996-2000. In our analysis we use firms with at least 20 employees.

In the firm-level panel between 1990-2000, we restrict our sample to those firms that are observed for at least five years. This means that for Swedish firms acquired by a foreign owner at period $(\mathrm{t})$, we only consider firms that are Swedish owned at $(\mathrm{t}-1)$ and remain foreign owned at year $(\mathrm{t}+1)$ to $(\mathrm{t}+3)$.

In the individual-level analysis on matched data for 1996-2000 we make similar restrictions. For these data we only consider firms that are observed for four consecutive years. The same restriction applies to individuals. With this restriction we can, in the foreign acquisition part of the paper, study firms that are acquired 1997 or 1998. We make the same survival criterion for the control group of non-acquired 
Swedish firms. As for firms, we restrict individuals to remain in the same firm during the period of observation of the firm. This restriction enables us to control for both individual and firm-specific effects when analyzing the impact of foreign ownership on wages.

\section{Descriptive Statistics}

There was a substantial increase of foreign ownership in the Swedish economy during the first half of the 1990s. As seen in Figure 1, the foreign share of value added increased from about 15 percent in 1990 to about 21 percent in 1996, a share that has remained relatively stable since then.

- Figure 1 about here-

The same pattern is seen for the foreign share of employment, although with slightly smaller shares, which suggest that labor productivity is higher in foreign firms. Finally, the foreign share of the number of firms is substantially smaller, showing foreign firm to be larger than the average Swedish-owned firm. The increased foreign share of Swedish industry corresponds to similar developments in many countries, but it might have been comparably large in Sweden (e.g. OECD, 2002). There are several reasons for this development. For instance, the deregulation of capital and foreign exchange markets in the late 1980s opened up Sweden for inflows of FDI. Two other important factors include the Swedish membership in the European Union in 1995 and the large currency crisis in 1992. The latter reduced the cost of Swedish assets and the cost of locating production in Sweden.

-Table 1 about here.- 
Table 1 shows a comparison of domestic- and foreign owned firms in Sweden. Wages are about 20 percent higher in foreign- as compared to domestically owned Swedish firms. Foreign firms locating in high-wage sectors do not seem to cause the high foreign wage; foreign firms pay higher wages in all sectors in 1990 and in all sectors except in Electronics and Transport Equipment in 2000.

The higher wages in foreign-owned firms might be caused by firm characteristics. For instance, skilled individuals have comparably high wages, and large firms tend to pay higher wages than small firms. Table 1 includes comparison of these factors in foreign- and domestically-owned firms. High skill is measured as the share of the workforce with at least tertiary education and size as the number of employees. Foreign-owned firms have a relatively well-educated workforce; the share of workers with higher education is twice as high as in domestically owned firm in 1990, but decreases to about 70 percent higher in 2000 . The pattern of comparable skilled workers in foreign-owned firms is found in almost all sectors and in both years. Moreover, foreign-owned firms are larger than domestically owned firms, and the difference has increased over the period. However, there are differences between industries and across the two years.

\section{Empirical Set-Up}

\section{Firm-level analysis}

We begin our analysis by examining the effect of ownership on wages at the firm level departing from the following expression:

$$
\ln w_{j t}=\beta_{0}+\beta_{1} O_{j t}+\mathrm{F}_{j t}^{\prime} \beta_{2}+\eta_{j}+\varepsilon_{j t}
$$


where wage is the average wage at firm $j$ at time $t$. Ownership is captured by $O$, a dummy variable for foreign ownership, defined as 1 if at least 50 percent of the equity is foreign owned. We will analyze the stock of foreign owned firms, foreign takeovers as well as greenfields. ${ }^{4}$ To isolate the impact of multinational status, we compare foreign owned firms with both Swedish multinationals and Swedish local firms. A firm is classified as being a multinational if they are reporting positive export to other firms within the same concern. $F$ is a vector of firm level variables such as (log) firm size, profits per employee, capital intensity, export intensity, categorical variables capturing the educational level of the employees, share of women, labor productivity and industry affiliation, $\eta_{j}$ is fixed firm effects and $\varepsilon$ is the error term.

\section{Individual-level analysis}

We continue with estimates of individual wage equations using the matched panel of firms and individuals. Micro data on individuals allows us to take into account within firm variation and worker heterogeneity. We use the following empirical specification in the individual-level analysis:

$$
\ln w_{i j t}=\beta_{0}+\beta_{1} O{ }_{j t}+\mathrm{X}_{i j t}^{\prime} \beta_{2}+\mathrm{F}_{j t}^{\prime} \beta_{3}+\alpha_{i}+\eta_{j}+\varepsilon_{i t}
$$

where $w_{i t}$ is the full-time equivalent monthly wage for worker $i$ at time $t ; O$ is a foreign ownership dummy for firm $j ; X$ is a vector with individual characteristics including gender, education, labor market experience and job-type; and $F$ contains firm level variables. Finally, $\alpha_{i}$ and $\eta_{j}$ are fixed individual- and firm-effects, respectively and $\varepsilon_{\mathrm{it}}$ is the error term.

\section{Propensity score matching}

\footnotetext{
${ }^{4}$ We define greenfield investment as a new established firm that is foreign owned.
} 
An econometric problem in estimating the causal effect of foreign ownership on wages concerns the endogeneity of firms becoming foreign owned. In other words, it is not random which firms that are acquired. Firms that become foreign owned might exhibit characteristics that systematically differ from other domestic firms. Moreover, and analogous to the problem in the evaluation literature of non-random treatment groups, the characteristics of the firms that become foreign owned might be such that they in any case would develop differently than their non-acquired counterparts. This, in turn, means that estimates on outcome variables (such as wages) become biased. In the case of foreign ownership and wages, the non-random sample of foreign firms can lead to an upward bias on the effect of foreign ownership on wages. We approach this problem by way of propensity score matching combined with the more general difference-in-differences (d-i-d) technique.

The aim of the matching procedure is to find a group of non-acquired firms that display the same characteristics as the group of acquired firms. Matching techniques allows us to relax the assumption of common coefficients across the total sample of acquired and non-acquired firms. Given that coefficients differ across groups OLS yields biased estimates. How much of the OLS-bias that is removed by the matching depends crucially on the identification of the characteristics that determine acquisitions (Heckman et al. (1998), Becker and Ichino (2002)). Table A3 shows the estimated logit-model of being acquired by a foreign owner, conditional on a variety of covariates that are important in explaining acquisitions. We use the algorithms provided by Becker and Ichino (2002) and Leuven and Sianesi (2003) for the matching. The propensity score is estimated with the Nearest-Neighbor method without replacements. The balancing property of the propensity score is tested and 
satisfied in all estimations. ${ }^{5}$ Since we have a panel of firms and individuals over time, the matching of firms is first calculated year-by-year using lagged covariates. The matched firms are then used in the analysis to create a panel of firms and individuals. Finally, to evaluate the impact of foreign acquisition we combine the matching procedure with difference-in-difference estimations, as suggested by Blundell and Costa Dias (2000). Using difference-in-difference estimations allow us to examine the dynamic effects of foreign takeovers on wages.

\section{Results}

\section{Firm-level Analysis}

We follow the previous literature and start by examining the average level of wages per employee at the firm level in Table 2.

-Table 2 about here.-

Estimation 1 shows that wages are 20 percent higher in foreign-owned firms compared to wages in domestically owned firms, even after controlling for industry and time effects. However, domestic and foreign owned firms differ in several respects, which might also affect wages. The rest of the estimations in Table 2 try to control for such differences in worker and firm characteristics. Estimation 2 includes characteristics of the workforce that presumably affect wages: the average skill level of employees and the share of female workers. Including these characteristics increases the R-square value substantially and reduces the wage premium in foreign

\footnotetext{
${ }^{5}$ To test for this, the sample is split into intervals of the propensity score. Within these intervals, the algorithm tests that the means of the covariates in the logit do not differ between treated and control observations. In testing the balancing property, only observations in the region of common support are included.
} 
owned firms to about 12 percent. This means that the impact of foreign ownership on wages can to a large extent be explained by worker characteristics, suggesting that it is important to control for worker heterogeneity. Moreover, a high share of female workers decreases average wages and a high share of high-skilled workers has a positive, albeit small, effect on average wages. ${ }^{6}$ Estimation 3 includes a set of other firm characteristics that in previous studies have been found to affect wages. Large firms pay relatively high wages, as do capital-intensive firms. The coefficient for profits per employee is positive and statistically significant but of rather small size.

In model 4, both human-capital and firm characteristics are included. The estimated coefficient on the foreign ownership variable of 0.12 is identical to the one in column 2, indicating that employee characteristics are more important than firm characteristics in explaining the foreign wage premium.

Models 5 and 6 compare foreign-owned firms with domestically-owned multinationals and local firms. The results show that the difference is much smaller between foreign-owned and domestically-owned multinationals than between foreignowned and local firms. Hence, a large part of the difference in wages between foreign- and domestically-owned firms is explained by multinational status alone. ${ }^{7}$ Finally, estimation 7 includes a number of other factors that might affect wages: the firm's export orientation, the degree of market competition and labor productivity. Export and productivity have statistically significant coefficients but the economic significance is small. Including all control variables in estimation 7 reduces the wage premium in foreign owned firms from 12 to about 11 percent, which is broadly in line with estimates in previous studies on firm level data for developed countries. ${ }^{8}$

\footnotetext{
${ }^{6}$ The group of comparison for the two skill variables are workers with intermediate skills (education).

${ }^{7}$ See Dorms and Jensen (1998) and Bellak (2004) for a similar discussion.

${ }^{8}$ See footnotes 1 and 2 for references.
} 
Foreign firms might enter in Sweden either by setting up a greenfield investment or by acquiring an existing Swedish-owned firm. It may not be obvious why a foreign acquisition should raise wages for workers that are already employed in the firm but a greenfield investor must attract new workers to the firm. One way to attract workers is to offer higher wages. Moreover, a greenfield investor might pay a wage premium due to a lack of knowledge about the local labor market. In Table 3, we present wage regressions where foreign ownership has been divided into greenfield investments and foreign takeovers of Swedish firms. An additional benefit with this distinction is that using information on foreign takeovers allows us to examine the impact of ownership change. If high wages in foreign owned firms were caused by unobservable firm specific characteristics, rather than by ownership itself, we would not expect any statistical significant effect of foreign takeovers.

-Table 3 about here.-

The wage premium of foreign greenfield investments is similar to the overall effect of foreign ownership on wages while the foreign acquisition premium is well below the greenfield estimates. To be precise, greenfield investors pay about 11 percent higher wages than domestically-owned Swedish firms, 5 percent higher than Swedish MNEs and 13 percent higher than Swedish locally-owned firms. The corresponding numbers for acquisitions are 7, 2 and 8 percent. Hence, the effect of foreign takeovers is only about 50 percent to two third as high as the effect of greenfield investments. ${ }^{9}$

\footnotetext{
${ }^{9}$ One reason for observing higher wage in foreign greenfield investments than in foreign takeovers could be due to a difference in the experience of the employees. However, controlling for the age of the firms did not have any significant impact on the results.
} 
We have also estimated firm-fixed effect models to take into account unobservable effects. Including firm fixed-effects further reduces the coefficient for foreign takeover to 1-2 percent, depending on specification. Comparing foreign takeovers with Swedish multinationals give rise to a non-significant effect (see column 6). Again, this stresses the importance in separating between domestic multinationals and domestic local firms.

\section{Individual-level Analysis}

As discussed above, there are reasons why an analysis at the individual level rather than at the firm level is suitable when studying the effect of ownership on wages. In Table 4 we present results from estimating individual wage equations.

-Table 4 about here.-

One striking result is that the firm level estimates differ radically from the corresponding individual level estimation. The estimated wage premium in foreign owned firms is substantially reduced when we change from firm level to individual level estimations. To be precise, estimation 1 in Table 4 shows that the unconditional wage premium is around 4 percent but the premium decreases to about 3 percent after inclusion of worker characteristics and to 2 percent after inclusion of both worker and firm characteristics. Corresponding figures from the firm level analysis were 20, 12 and 11 percent. Moreover, there is no difference in wages between employees in foreign-owned firms and in domestically-owned multinational firms. Hence, our 
previous conclusion remains: multinational status is more important for wages than the nationality of the firm. ${ }^{10}$

One explanation for the different results between firm- level and individuallevel based estimations might stem from the correlation between firm size and multinationality. ${ }^{11}$ Large firms tend to be multinationals and Swedish and foreign owned multinationals have been shown to pay similar wages. We test this hypothesis by way of estimating employment-weighted firm-level regressions. Analogously, in the individual wage regressions we down-weight firms by the inverse of firm size. ${ }^{12}$ The weighting brings the firm- and individual level regression results somewhat closer to each other, but they remain significantly different. ${ }^{13}$

Note also that by estimating individual level regressions we escape wage effects caused by changes in the labor force composition. This could arise if foreign firms replace less productive (low wage) workers with more skilled (high-wage) workers. In this case the estimated foreign ownership premium is a composition effect rather than an effect of ownership.

Looking at the other coefficients suggest that female wages are about 14 percent lower than male wages and that blue-collar workers have about 11 percent lower wages than white-collar workers. Moreover, wages and experience follow the classical inverted U-shaped pattern. Regarding firm characteristics, it is seen that capital intensity has an economically significant effect on wages; size, profits, and the

\footnotetext{
${ }^{10}$ Lipsey (2004) argues that the comparison of foreign- and domestically owned MNEs might be biased since the latter group includes headquarter services, with comparable high wages. It is likely that at least some of this bias is controlled for by our relatively detailed information on worker characteristics. ${ }^{11}$ The different results are not caused by different time periods. Running the firm-level regressions for the period 1996-2000 did not upset results.

${ }^{12}$ Weighting of firm-level model 4 in Table 2 decreased the estimated foreign ownership wage premium from 12 to roughly 7 percent. Analogously, in the individual wage regressions the estimated foreign wage premium in model 3 in Table 4 increased from 2 to 5 percent. These results are available on request.
} 
average skill level of workers are statistically significant but with small coefficients. ${ }^{14}$ To take into account that observations might be correlated within firms, we have reestimated all equations, controlling for within-firm error correlations. This did not upset the significance of our results. ${ }^{15}$

\section{Individual wages, mergers and acquisitions}

In the previous section we analyzed differences between foreign- and domestically owned firms. If there is a positive effect of foreign ownership on the wages received by individual workers, we expect this to show up in an analysis of foreign acquisitions. However, we would not expect any effect of foreign acquisitions if it is unobserved attributes of the workers that cause their higher wages. Moreover, foreign acquisitions may be non-random. For instance, high wage firms may be acquired more frequently than low wage firms. This suggests that matching techniques may improve the estimates. Table 5 presents results on both our matched and unmatched sample.

-Table 5 about here.-

Results from model 1 and 2 in Table 5 suggest a wage premium in acquired firms comparable with the wage premium obtained for the whole stock of foreign owned firms. Columns 4-6 present results from estimating models on the matched sample of similar firms that remain domestically owned. Taking selection bias into

\footnotetext{
${ }^{13}$ Similar result are found in both the firm size and the rent sharing literature where the estimated effect of firm size and profits on wages are significantly reduced when changing from firm- to individual level estimations (see e.g. Oi and Idson (1999) and Arai (2003) and references therein).

${ }^{14}$ The average skill level of employees aims at capturing complementarities with individual wages. Individual wages can for instance be positively correlated with the share of high skilled workers in the firms through externalities.
} 
account, the estimated impact of foreign ownership becomes virtually zero, indicating that for individual workers there is no foreign wage premium.

However, the wage premium may not be determined by observables only, unobservables may also matter. In model 3 and 6 we control for unobservables by estimating fixed-effect models. Since we have restricted the sample to workers remaining in the same firm the entire period of observation of the firm, we obtain within individual and within firm estimates. This means that we control for both time invariant individual- and firm-specific effects, thus accounting for a systematic sorting of individuals across firms. The inclusion of fixed-effects has a large impact on the foreign ownership wage premium. This is especially true for the unmatched sample where the fixed-effect estimation reduces the wage premium from two to minus four percent. Finally, in column 6 we estimate a fixed-effect model on our matched sample, taking into account both the issue of unobservables and selection bias. This results in a reduction of the estimated coefficient on foreign acquisition from minus four percent to minus two percent.

To see whether it is the "shake-out" that typically occurs after an acquisition or ownership that drives the results we also looked at foreign firms that become Swedish owned. Estimating the same full model specification as in column 2, Table 5, the estimated impact of becoming Swedish owned is slightly negative. This suggests that the impact of foreign and domestic acquisitions differs. ${ }^{16}$

To visualize how wages evolve after an acquisition we depict wage trajectories for acquired and non-acquired firms (see Figure 2). Figure 2 indicate that foreign owners target high-wage firms and that the wage actually decreases (increases but at a

\footnotetext{
${ }^{15}$ Available on request.

${ }^{16}$ Results available on request.
} 
lower rate) after the change in ownership. This is visualized by converging wage trajectories of acquired and non-acquired firms. ${ }^{17}$

-Figure 2 about here-

We now proceed to study wage dynamics for individuals in acquired and nonacquired firms by means of combining matching and difference-in-difference techniques. Blundell and Costa Dias (2000) show that such combining of matching techniques with difference-in-difference techniques may improve non-experimental evaluation results significantly. As described in the Empirical Set-Up, the purpose of the matching procedure is to take into account the endogeneity of foreign acquisitions and possible selection bias. Combining matching with difference-in-difference analysis allows us to follow the wage dynamics over time, comparing wage growth between acquired and non-acquired control firms over time.

Results from the difference-in-difference regressions are presented in Table 6. The growth rate of wages in targeted firms one respectively two years after acquisition is compared to the year prior to acquisition. ${ }^{18}$

-Table 6 about here-

Results verify the picture given in Figure 2. Firstly, the wage level is 2-6 percent higher in acquired firms than in the group of matched non-acquired firms. Secondly, the wage growth in acquired firms is lower than in firms that do not

\footnotetext{
${ }^{17}$ Acquisitions at time $t$ occur in 1997 or 1998. Wages in non-acquired firms at time $t$ is defined as average wages in non-acquired firms for the period 1997-1998. For subsequent periods we calculate a moving average.

${ }^{18}$ These effects refer to $(\mathrm{t}+1)-(\mathrm{t}-1)$ and $(\mathrm{t}+2)-(\mathrm{t}-1)$ in Table 6 .
} 
become foreign owned. More specifically, the variable Foreign captures the wage difference between individuals in firms that are taken over by foreign owners and individuals in firms that remain domestically owned. The coefficients suggest that individuals in takeovers have a wage level that is about 2-6 percent higher than individuals in other firms depending on specification. However, the wage growth is higher in non-takeovers, as seen from the variable foreign takeover. The estimated coefficient, examining both the effect $t+1$ and $t+2$, suggests that wages grow slower for individuals in firms taken over by foreign owners compared to wages for individuals in other firms. This effect is stronger after two years than after one year (compare columns 3 and 6).

The results from our analysis suggest that a large share of observed differences in wages between foreign and domestic firms can be attributed to differences in observable and unobservable characteristics of firms and workers. Foreign firms do not seem to pay higher wages than domestic firms do for identical types of workers.

\section{Concluding Remarks}

We have in this paper examined the effect of ownership on wages. More precisely, we have used a large matched employer-employee data set to address the question of whether foreign-owned firms pay higher wages than domestically owned firms and whether foreign-owned firms pay higher wages for identical workers? The first question can without any doubt be answered positively: foreign-owned firms pay higher wages than domestically-owned firms. However, there is no evidence that foreign firms pay higher wages for identical workers. Instead, higher wages in foreign-owned firms are caused by differences in firm and worker characteristics. In 
this respect, worker characteristics is found to be more important than firm characteristics in estimating the foreign ownership wage premium.

Results suggest that it is the difference between multinational and nonmultinational firms, rather than between domestic- and foreign-owned firms, that is important. Foreign-owned firms tend to pay higher wages than domestically-owned firms without foreign affiliates, but do not pay higher wages than domestically-owned multinational firms.

We also find a large difference in results between firm-level and individuallevel data. Firm level results tend to overestimate the wage premium in foreign-owned firms, presumably because foreign- and domestically-owned firms are distributed differently over size categories. Firm-level results might therefore be biased by a comparison of, on average, relatively large foreign-owned firms with relatively small non-multinational domestically-owned firms.

We also investigated how the mode of entry affects wages. Foreign owned firms might enter the market by a greenfield investment or through acquisition of a Swedish owned firm. We therefore compare foreign greenfield investments with foreign acquisitions. The results suggest that in order to attract new workers greenfield investors have to pay a wage premium.

To deal with the issue of unobservables and selection bias in foreign acquisitions, we combine matching techniques with difference in differences estimations. Results suggest that foreign owners target high-wage firms and that, compared to non-targeted firms, wages increase at a lower rate after the change in ownership. Hence, for an individual worker, if anything, the change in ownership implies a less positive wage growth. 
Our result has some important implications. Firstly, previous firm-level studies on ownership and wages presumably exaggerate the foreign wage premium. Secondly, our results show that it is important to control for worker heterogeneity and for selection bias in foreign acquisitions. Controlling for these factors yield results indicating no systematic differences in wages between domestic and foreign-owned firms. Finally, our results suggest that it is important to focus on the difference between multinational and non-multinational firms, rather than comparing foreignand domestically owned firms.

\section{References}

Aitken, Brian, Anne E. Harrison and Robert E. Lipsey (1996), "Wages and Foreign Ownership: A Comparative study of Mexico, Venezuela, and the United States", Journal of International Economics, Vol. 40, pp. 345-71.

Arai, Mahmood (2003), "Wages, Profits and Capital Intensity: Evidence from Matched Worker-Firm Data", Journal of Labor Economics, Vol. 97, no. 5, 1027-1059.

Becker, Sascha and Andrea Ichino (2002), "Estimation of average treatment effects based on propensity score", The Stata Journal, Vol. 2, No. 4, pp. 358-377

Bellak, Christian (2004), "How Domestic and Foreign Firms Differ and Why Does it Matter?", Journal of Economic Surveys, Vol. 18, no. 4, pp. 483-514.

Bernard, Andrew B. and Fredrik Sjöholm (2003), "Foreign Owners and Plant Survival", NBER Working Paper No. 10039.

Blundell, Richard and Costa Dias, Monica (2000), "Evaluation Methods for nonexperimental data", Fiscal Studies, vol. 21, no. 4, pp. 427-468

Bora, Bijit and Mark Wooden (1998), "Human Capital, Foreign Ownership and Wages", mimeo, Flinders University.

Budd, John W., Josef Konings and Matthew J. Slaughter (2002), "International Rent Sharing in Multinational Firms", NBER Working Paper No. 8809, forthcoming Review of Economics and Statistics.

Conyon, Martin, Sourafel Girma, Steve Thompson, and Peter Wright (2002), "The Productivity and Wage Effects of Foreign Acquisition in the United Kingdom”, Journal of Industrial Economics, vol. L, pp. 85-102. 
Doms, Mark E., and J.Bradford Jensen (1998), ”Comparing Wages, Skills, and Productivity between Domestically and Foreign-Owned Manufacturing Establishments in the United States, in Robert E. Baldwin, Robert E. Lipsey, and J. David Richardson (Eds.), Geography and Ownership as Bases for Economic Accounting, Studies in Income and Wealth, Vol. 59, Chicago, University of Chicago Press, pp. 235-258.

Driffield, Nigel and Sourafel Girma (2001), "Regional Foreign Direct Investment and Wage Spillovers: Plant Level Evidence from the Electronics Industry”, Research paper 2002/04, Leverhulme Centre for Research on Globalisation and Economic Policy, Nottingham, University of Nottingham.

Fabbri, Francesca, Jonathan E. Haskel and Matthew J. Slaughter (2003), "Does Nationality of Ownership Matter for Labor Demands?", Journal of the European Economic Association, Papers and Proceedings, Vol. 1, pp. 698-707.

Fosfuri, Andrea, Motta Massimo, and Thomas Ronde (2001), "Foreign Direct Investments and Spillovers through Workers' Mobility", Journal of International Economics, Vol. 53, pp.205-222.

Girma, Sourafel, David Greenaway, and Katherine Wakelin (2001), "Who Benefits from Foreign Direct Investment in the UK?", Scottish Journal of Political Economy, Vol. 48, No. 2, pp. 119-133.

Görg, Holger, Strobl, Eric, and Frank Walsh (2002), Why Do Foreign-Owned Firms Pay More? The Role of On-the-Job Training”, GEP Research Papers No 2002/15, Nottingham University.

Griffith, Rachel (1999), "Using the ARD Establishment Level Data to Look at Foreign Ownership and Productivity in the United Kingdom", Economic Journal, Vol. 109, pp. 416-442.

Haddad, Mona, and Ann Harrison (1993), "Are There Positive Spillovers from Direct Foreign Investment?”, Journal of Development Economics, Vol. 42, pp.51-74.

Heckman, James J., Hidehiko Ichimura, and Petra Todd (1998), "Matching as an Econometric Evaluation Estimator", Review of Economic Studies, 65, pp. 261-294.

Leuven, Edward and Barbara Sianesi (2003), "PSMATCH2: Stata module to perform full Mahalanobis and propensity score matching, common support graphing, and covariate imbalance testing", http://ideas.repec.org/c/boc/bocode/s432001.html. Version 1.2.3.

Lipsey, Robert E. (1994), "Foreign-Owned Firms and U.S. Wages”, NBER Working Paper No. 4927.

Lipsey, Robert E. (2004), "Home- and Host-Country Effects of Foreign Direct Investment," in Robert E. Baldwin and L. Alan Winters (Eds), Challenges to Globalization, Chicago, University of Chicago Press, forthcoming. 
Lipsey, Robert E. and Fredrik Sjöholm (2002), "Foreign Firms and Indonesian Manufacturing Wages: An Analysis with Panel Data", NBER Working Paper No. 9417.

Lipsey, Robert E. and Fredrik Sjöholm (2004), "Foreign Direct Investment, Education, and Wages in Indonesian Manufacturing", Journal of Development Economics, Vol. 73, pp. 415-422.

Martins, Pedro S. (2004), "Do Foreign Firms Really Pay Higher Wages? Evidence from Different Estimators”, mimeo, Queens Mary, University of London.

OECD (2001), Measuring Globalisation, Paris: OECD.

Oi, Walter Y. and Todd L. Idson (1999), "Firm Size and Wages", in: Ashenfelter, Orley C. and David Card (Eds), Handbook of Labor Economics, Elsevier Science B.V., Amsterdam, The Netherlands.

Ono, Hiroshi and Kazuhiko Odaki (2004), "Foreign Ownership and the Structure of Wages in Japan", Paper presented at the National Bureau of Economic Research Conference, Tokyo, Japan September 2004. 


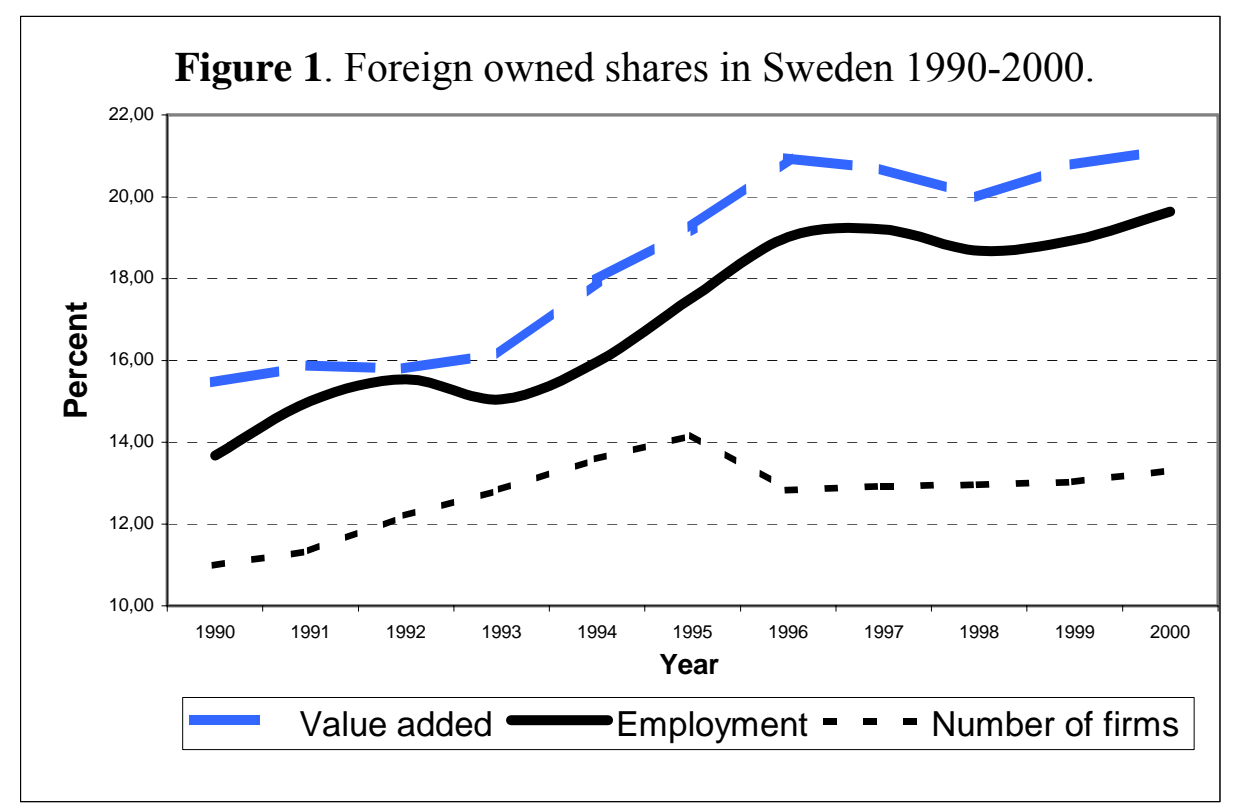

Table 1. Comparisons of foreign and domestically owned firms (Ratios).

\begin{tabular}{lccccccc}
\hline \multicolumn{1}{c}{ Industry } & & \multicolumn{3}{c}{ Mean wage } & \multicolumn{3}{c}{$\begin{array}{c}\text { Share of skilled } \\
\text { employees }\end{array}$} \\
& & \multicolumn{3}{c}{ Firm size } \\
Total & & 1990 & 2000 & 1990 & 2000 & 1990 & 2000 \\
\multicolumn{2}{l}{ Simple manufacturing (1) } & 1.04 & 1.21 & 2.12 & 1.70 & 1.30 & 3.52 \\
Wood and metals & $(2)$ & 1.10 & 1.12 & 2.49 & 1.77 & 2.38 & 2.11 \\
Electronics,transp. eq. (3) & 1.19 & 0.85 & 2.94 & 1.58 & 1.95 & 1.28 \\
Energy & $(4)$ & 1.13 & 1.04 & 2.19 & 1.42 & 1.76 & 0.96 \\
Retail trade & $(5)$ & 1.34 & 1.43 & 4.27 & 3.12 & 1.04 & 1.31 \\
Transport serv. & $(6)$ & 1.08 & 1.16 & 1.37 & 3.01 & 0.70 & 1.31 \\
Real estate & $(7)$ & 1.08 & 1.25 & 0.88 & 1.10 & 0.86 & 2.01 \\
\hline
\end{tabular}

Note: Share of skilled employees is constructed as the share of employees with at least tertiary education. 
Table 2. The effect of foreign ownership on wages. Firm-level estimates 1990-2000 (dependent variable - log wage per employee).

\begin{tabular}{|c|c|c|c|c|c|c|c|}
\hline & 1 & 2 & 3 & 4 & 5 & 6 & 7 \\
\hline & $\begin{array}{l}\text { vs. } \\
\text { All }\end{array}$ & $\begin{array}{l}\text { vs. } \\
\text { All }\end{array}$ & $\begin{array}{l}\text { vs. } \\
\text { All }\end{array}$ & $\begin{array}{l}\text { vs. } \\
\text { All }\end{array}$ & $\begin{array}{l}\text { vs. } \\
\text { Swe. } \\
\text { MNEs }\end{array}$ & $\begin{array}{l}\text { vs. } \\
\text { Swe. } \\
\text { Local } \\
\end{array}$ & $\begin{array}{l}\text { vs. } \\
\text { All }\end{array}$ \\
\hline Foreign & $\begin{array}{l}0.20 * * * \\
(0.00)\end{array}$ & $\begin{array}{l}0.12 * * * \\
(0.00)\end{array}$ & $\begin{array}{l}0.19 * * * \\
(0.00)\end{array}$ & $\begin{array}{l}0.12^{* * * *} \\
(0.00)\end{array}$ & $\begin{array}{l}0.05 * * * \\
(0.00)\end{array}$ & $\begin{array}{l}0.13 * * * \\
(0.00)\end{array}$ & $\begin{array}{l}0.11 * * * \\
(0.00)\end{array}$ \\
\hline High skilled & -- & $\begin{array}{l}0.01 * * * \\
(0.00)\end{array}$ & -- & $\begin{array}{l}0.01 * * * \\
(0.00)\end{array}$ & $\begin{array}{l}0.01 * * * \\
(0.00)\end{array}$ & $\begin{array}{l}0.00 * * * \\
(0.00)\end{array}$ & $\begin{array}{l}0.01 * * * \\
(0.00)\end{array}$ \\
\hline Low skilled & -- & $\begin{array}{l}-0.00 * * * \\
(0.00)\end{array}$ & -- & $\begin{array}{l}-0.00 * * * \\
(0.00)\end{array}$ & $\begin{array}{l}-0.00 \\
(0.00)\end{array}$ & $\begin{array}{l}-0.00 * * * \\
(0.00))\end{array}$ & $\begin{array}{l}-0.00 * * * \\
(0.00)\end{array}$ \\
\hline Female & -- & $\begin{array}{l}-0.23 * * * \\
(0.00)\end{array}$ & -- & $\begin{array}{l}-0.20 * * * \\
(0.00)\end{array}$ & $\begin{array}{l}-0.16^{* * *} \\
(0.02)\end{array}$ & $\begin{array}{l}-0.20 * * * \\
(0.01))\end{array}$ & $\begin{array}{l}-0.20 * * * \\
(0.01)\end{array}$ \\
\hline Log Firm size & -- & -- & $\begin{array}{l}0.02 * * * \\
(0.00)\end{array}$ & $\begin{array}{l}0.00 * * * \\
(0.00)\end{array}$ & $\begin{array}{l}-0.01 * * * \\
(0.00)\end{array}$ & $\begin{array}{l}-0.00 * \\
(0.00)\end{array}$ & $\begin{array}{l}0.00 \\
(0.00)\end{array}$ \\
\hline Profits/Employee & -- & -- & $\begin{array}{l}0.00 * * * \\
(0.00)\end{array}$ & $\begin{array}{l}0.00^{* * * *} \\
(0.00)\end{array}$ & $\begin{array}{l}0.00 * * * \\
(0.00)\end{array}$ & $\begin{array}{l}0.00 * * * \\
(0.00)\end{array}$ & $\begin{array}{l}0.00 * * * \\
(0.00)\end{array}$ \\
\hline Capital intensty & -- & -- & $\begin{array}{l}0.04 * * * \\
(0.00)\end{array}$ & $\begin{array}{l}0.03^{* * * *} \\
(0.00)\end{array}$ & $\begin{array}{l}0.04 * * * \\
(0.01)\end{array}$ & $\begin{array}{l}0.03 * * * \\
(0.00)\end{array}$ & $\begin{array}{l}0.03 * * * \\
(0.00)\end{array}$ \\
\hline Export share & -- & -- & -- & -- & -- & -- & $\begin{array}{l}0.00 * * * \\
(0.00)\end{array}$ \\
\hline Herfindahl & -- & -- & -- & -- & -- & -- & $\begin{array}{l}0.00 \\
(0.00)\end{array}$ \\
\hline Labor productivity & -- & -- & -- & -- & -- & -- & $\begin{array}{l}0.00 * * * \\
(0.00)\end{array}$ \\
\hline Time dummies & included & included & included & included & included & included & included \\
\hline Industry dummies & included & included & included & included & included & included & included \\
\hline Adj. R-sq. & 0.19 & 0.41 & 0.23 & 0.43 & 0.45 & 0.42 & 0.45 \\
\hline No. of obs. & 61,520 & 61,520 & 60,670 & 60,670 & 13,662 & 54,930 & 60,670 \\
\hline
\end{tabular}

Note: Robust standard errors within brackets. * - significant at a ten percent level; ** - significant at a five percent level; *** - significant at a one percent level. Industry dummies correspond to 14 industries. 
Table 3. The effect of greenfields and foreign takeovers on wages. Firm-level estimates 1990-2000 (dependent variable - log wage per employee).

\begin{tabular}{|c|c|c|c|c|c|c|c|c|c|}
\hline & 1 & 2 & 3 & 4 & 5 & 6 & 7 & 8 & 9 \\
\hline & \multicolumn{3}{|c|}{ vs. All } & \multicolumn{3}{|c|}{ vs. SWE. MNEs } & \multicolumn{3}{|c|}{ vs. Swe Local } \\
\hline Greenfield & $\begin{array}{l}0.11 \\
(.00)^{* * *}\end{array}$ & -- & -- & $\begin{array}{l}0.05 \\
(.00) * * *\end{array}$ & -- & -- & $\begin{array}{l}0.13 \\
(.00)^{* * * *}\end{array}$ & -- & -- \\
\hline $\begin{array}{l}\text { Foreign } \\
\text { Takeover }\end{array}$ & -- & $\begin{array}{l}0.07 \\
(0.01)^{* * *}\end{array}$ & $\begin{array}{l}0.01 \\
(0.01)^{*}\end{array}$ & -- & $\begin{array}{l}0.02 \\
(0.00)^{* * *}\end{array}$ & $\begin{array}{l}0.01 \\
(0.01)\end{array}$ & -- & $\begin{array}{l}0.08 \\
(0.01)^{* * *}\end{array}$ & $\begin{array}{l}0.02 \\
(0.01)^{*}\end{array}$ \\
\hline High skilled & $\begin{array}{l}0.01 \\
(.00) * * *\end{array}$ & $\begin{array}{l}0.01 \\
(0.00)^{* * *}\end{array}$ & $\begin{array}{l}0.0 \\
(0.00) * * *\end{array}$ & $\begin{array}{l}0.01 \\
(.00)^{* * *}\end{array}$ & $\begin{array}{l}0.01 \\
(0.00) * * *\end{array}$ & $\begin{array}{l}0.00 \\
(0.00)^{* * *}\end{array}$ & $\begin{array}{l}0.01 \\
(.00) * * *\end{array}$ & $\begin{array}{l}0.01 \\
(0.00) * * *\end{array}$ & $\begin{array}{l}0.00 \\
(0.00)^{* * *}\end{array}$ \\
\hline Low skilled & $\begin{array}{l}-0.00 \\
(.00)^{* * *}\end{array}$ & $\begin{array}{l}-0.00 \\
(0.00)^{* * *}\end{array}$ & $\begin{array}{l}-0.00 \\
(0.00)^{* * *}\end{array}$ & $\begin{array}{l}-0.00 \\
(.00)^{* * *}\end{array}$ & $\begin{array}{l}-0.00 \\
(0.00)^{* * *}\end{array}$ & $\begin{array}{l}-0.00 \\
(0.00)^{* * *}\end{array}$ & $\begin{array}{l}-0.00 \\
(.00)^{* * *}\end{array}$ & $\begin{array}{l}-0.00 \\
(0.00)^{* * *}\end{array}$ & $\begin{array}{l}-0.00 \\
(0.00)^{* * *}\end{array}$ \\
\hline Female & $\begin{array}{l}-0.20 \\
(.01)^{* * *}\end{array}$ & $\begin{array}{l}-0.20 \\
(0.01)^{* * *}\end{array}$ & $\begin{array}{l}-0.07 \\
(0.02)^{* * *}\end{array}$ & $\begin{array}{l}-0.15 \\
(.02)^{* * *}\end{array}$ & $\begin{array}{l}-0.17 \\
(0.02)^{* * *}\end{array}$ & $\begin{array}{l}-0.07 \\
(0.07)\end{array}$ & $\begin{array}{l}-0.19 \\
(.01)^{* * *}\end{array}$ & $\begin{array}{l}-0.19 \\
(0.01)^{* * *}\end{array}$ & $\begin{array}{l}-0.08 \\
(0.02)^{* *}\end{array}$ \\
\hline Log Firm size & $\begin{array}{l}0.01 \\
(.00) * * *\end{array}$ & $\begin{array}{l}0.01 \\
(0.00) * * *\end{array}$ & $\begin{array}{l}-0.10 \\
(0.00)^{* * *}\end{array}$ & $\begin{array}{l}-0.01 \\
(.00)^{* * *}\end{array}$ & $\begin{array}{l}-0.00 \\
(0.00)^{* * *}\end{array}$ & $\begin{array}{l}-0.07 \\
(0.01)^{* * *}\end{array}$ & $\begin{array}{l}-0.00 \\
(.00)\end{array}$ & $\begin{array}{l}0.00 \\
(0.00)^{* * *}\end{array}$ & $\begin{array}{l}-0.10 \\
(0.00)^{* * *}\end{array}$ \\
\hline Profits/Employee & $\begin{array}{l}0.00 \\
(.00)^{* * * *}\end{array}$ & $\begin{array}{l}0.00 \\
(0.00) * * *\end{array}$ & $\begin{array}{l}0.00 \\
(0.00)^{* * *}\end{array}$ & $\begin{array}{l}0.00 \\
(.00)^{* * *}\end{array}$ & $\begin{array}{l}0.00 \\
(0.00) * * *\end{array}$ & $\begin{array}{l}0.00 \\
(0.00) * * *\end{array}$ & $\begin{array}{l}0.00 \\
(.00)^{* * * *}\end{array}$ & $\begin{array}{l}0.00 \\
(0.00)\end{array}$ & $\begin{array}{l}0.00 \\
(0.00)^{* * *}\end{array}$ \\
\hline Capital intensity & $\begin{array}{l}0.03 \\
(.00)^{* * * *}\end{array}$ & $\begin{array}{l}0.03 \\
(0.00) * * *\end{array}$ & $\begin{array}{l}0.04 \\
(0.00) * * *\end{array}$ & $\begin{array}{l}0.05 \\
(.01)^{* * *}\end{array}$ & $\begin{array}{l}0.04 \\
(0.01) * * *\end{array}$ & $\begin{array}{l}0.08 \\
(0.00)^{* * *}\end{array}$ & $\begin{array}{l}0.03 \\
(.00)^{* * * *}\end{array}$ & $\begin{array}{l}0.03 \\
(0.00)^{* * *}\end{array}$ & $\begin{array}{l}0.04 \\
(0.00)^{* * *}\end{array}$ \\
\hline $\begin{array}{l}\text { Fixed effects } \\
\text { Time dummies } \\
\text { Industry dum. }\end{array}$ & $\begin{array}{l}\text {-- } \\
\text { included } \\
\text { included }\end{array}$ & $\begin{array}{l}-- \\
\text { included } \\
\text { included }\end{array}$ & $\begin{array}{l}\text { included } \\
\text { included } \\
\text { included }\end{array}$ & $\begin{array}{l}\text {-- } \\
\text { included } \\
\text { included }\end{array}$ & $\begin{array}{l}-- \\
\text { included } \\
\text { included }\end{array}$ & $\begin{array}{l}\text { included } \\
\text { included } \\
\text { included }\end{array}$ & $\begin{array}{l}\text {-- } \\
\text { included } \\
\text { included }\end{array}$ & $\begin{array}{l}\text {-- } \\
\text { included } \\
\text { included }\end{array}$ & $\begin{array}{l}\text { included } \\
\text { included } \\
\text { included }\end{array}$ \\
\hline $\begin{array}{l}\text { Hausman } \\
\text { Adj. R-sq. } \\
\text { No. of obs. }\end{array}$ & $\begin{array}{l}-- \\
0.42 \\
60,670\end{array}$ & $\begin{array}{l}-- \\
0.41 \\
54,643\end{array}$ & $\begin{array}{l}3424 * * * \\
0.41 \\
54,643\end{array}$ & $\begin{array}{l}-- \\
0.42 \\
10,714\end{array}$ & $\begin{array}{l}-- \\
0.46 \\
7,441\end{array}$ & $\begin{array}{l}284 * * * \\
0.41 \\
7,441\end{array}$ & $\begin{array}{l}-- \\
0.41 \\
51,972\end{array}$ & $\begin{array}{l}-- \\
0.39 \\
48,785\end{array}$ & $\begin{array}{l}2156 * * * \\
0.41 \\
48,785\end{array}$ \\
\hline
\end{tabular}

Note: Robust standard errors within brackets. * - significant at a ten percent level; ** - significant at a five percent level; *** - significant at a one percent level. Industry dummies correspond to 14 industries. 
Table 4. The effect of foreign ownership on wages. Individual level estimates 1996-2000 (dependent variable - log monthly wage).

\begin{tabular}{|c|c|c|c|c|c|}
\hline & 1 & 2 & 3 & 4 & 5 \\
\hline & $\begin{array}{l}\text { vs. } \\
\text { All }\end{array}$ & $\begin{array}{l}\text { vs. } \\
\text { All }\end{array}$ & $\begin{array}{l}\text { vs. } \\
\text { All }\end{array}$ & $\begin{array}{l}\text { vs. } \\
\text { Swe. } \\
\text { MNEs }\end{array}$ & $\begin{array}{l}\text { vs. } \\
\text { Swe. } \\
\text { Local }\end{array}$ \\
\hline Foreign & $\begin{array}{l}0.04 \\
(0.00)^{* * *}\end{array}$ & $\begin{array}{l}0.03 \\
(0.00)^{* * *}\end{array}$ & $\begin{array}{l}0.02 \\
(0.00)^{* * *}\end{array}$ & $\begin{array}{l}0.00 \\
(0.00)^{* *}\end{array}$ & $\begin{array}{l}0.05 \\
(0.00)^{* * *}\end{array}$ \\
\hline Female & -- & $\begin{array}{l}-0.15 \\
(0.00)^{* * *}\end{array}$ & $\begin{array}{l}-0.14 \\
(0.00)\end{array}$ & $\begin{array}{l}-0.14 \\
(0.00)^{* * *}\end{array}$ & $\begin{array}{l}-0.14 \\
(0.00)^{* * *}\end{array}$ \\
\hline Education dummies & -- & included & included & included & included \\
\hline Experience & -- & $\begin{array}{l}0.02 \\
(0.00)^{* * *}\end{array}$ & $\begin{array}{l}0.02 \\
(0.00)^{* * *}\end{array}$ & $\begin{array}{l}0.02 \\
(0.00)^{* * *}\end{array}$ & $\begin{array}{l}0.02 \\
(0.00)^{* * *}\end{array}$ \\
\hline Experience $^{2}$ & -- & $\begin{array}{l}-0.00 \\
(0.00)^{* * *}\end{array}$ & $\begin{array}{l}-0.00 \\
(0.00)^{* * *}\end{array}$ & $\begin{array}{l}-0.00 \\
(0.00)^{* * *}\end{array}$ & $\begin{array}{l}-0.00 \\
(0.00)^{* * * *}\end{array}$ \\
\hline Blue-collar & -- & $\begin{array}{l}-0.13 \\
(0.00)^{* * *}\end{array}$ & $\begin{array}{l}-0.11 \\
(0.00)^{* * *}\end{array}$ & $\begin{array}{l}-0.12 \\
(0.00)^{* * *}\end{array}$ & $\begin{array}{l}-0.12 \\
(0.00)^{* * *}\end{array}$ \\
\hline Log Firm size & -- & -- & $\begin{array}{l}0.00 \\
(0.00)^{* * *}\end{array}$ & $\begin{array}{l}-0.01 \\
(0.00)^{* * *}\end{array}$ & $\begin{array}{l}0.00 \\
(0.00) * * *\end{array}$ \\
\hline Profits/Employee & -- & -- & $\begin{array}{l}0.00 \\
(0.00)^{* * *}\end{array}$ & $\begin{array}{l}0.00 \\
(0.00)^{* * *}\end{array}$ & $\begin{array}{l}0.00 \\
(0.00)^{* * * *}\end{array}$ \\
\hline High skilled & -- & -- & $\begin{array}{l}0.00 \\
(0.00)^{* * *}\end{array}$ & $\begin{array}{l}0.00 \\
(0.00)^{* * *}\end{array}$ & $\begin{array}{l}0.00 \\
(0.00)^{* * *}\end{array}$ \\
\hline Low skilled & -- & -- & $\begin{array}{l}0.00 \\
(0.00)^{* * *}\end{array}$ & $\begin{array}{l}-0.00 \\
(0.00)^{* * *}\end{array}$ & $\begin{array}{l}-0.00 \\
(0.00) * * *\end{array}$ \\
\hline Capital intensity & -- & -- & $\begin{array}{l}0.03 \\
(0.00)^{* * *}\end{array}$ & $\begin{array}{l}0.04 \\
(0.00) * * *\end{array}$ & $\begin{array}{l}0.02 \\
(0.00)^{* * *}\end{array}$ \\
\hline Time dummies & included & included & included & included & included \\
\hline Industry dummies & included & included & included & included & included \\
\hline Adj. R-sq. & 0.06 & 0.42 & 0.45 & 0.47 & 0.44 \\
\hline No. of observations & $1,627,908$ & $1,618,019$ & $1,614,172$ & 841,167 & $1,069,902$ \\
\hline
\end{tabular}

Note: Robust standard errors within brackets. * - significant at a ten percent level; ** - significant at a five percent level; *** - significant at a one percent level. Industry dummies correspond to 14 industries. 
Table 5. Wage effects of foreign takeovers of Swedish firms. Individual level estimates 1996-2000 (dependent variable - log monthly wage).

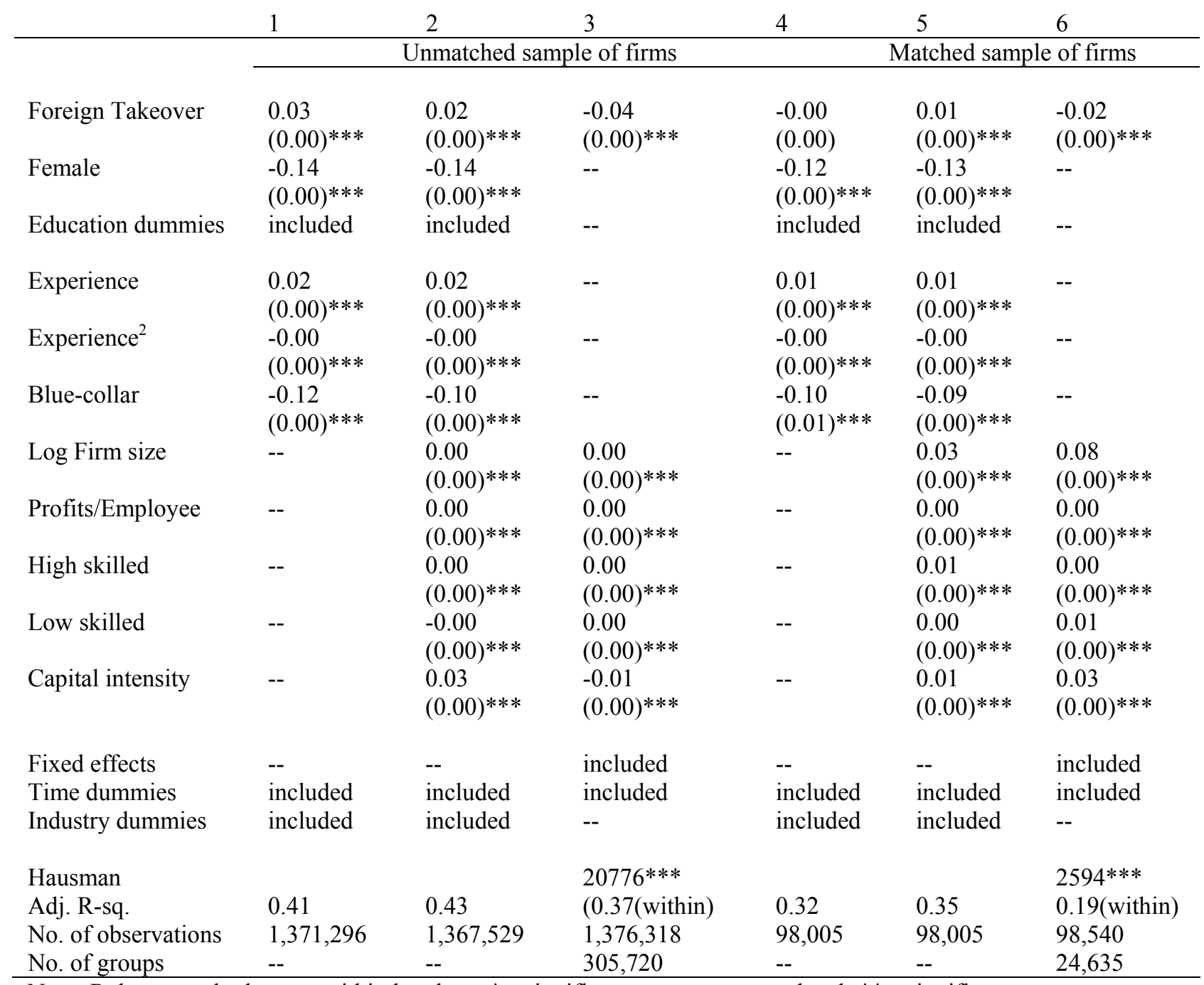

Note: Robust standard errors within brackets. ${ }^{*}$ - significant at a ten percent level; ${ }^{* *}$ - significant at a five percent level; $* * *$ - significant at a one percent level. Industry dummies correspond to 14 industries. 
Figure 2. Wage growth for individuals in firms that are acquired by a foreign owner and in firms that remain domestically owned (log monthly wage).

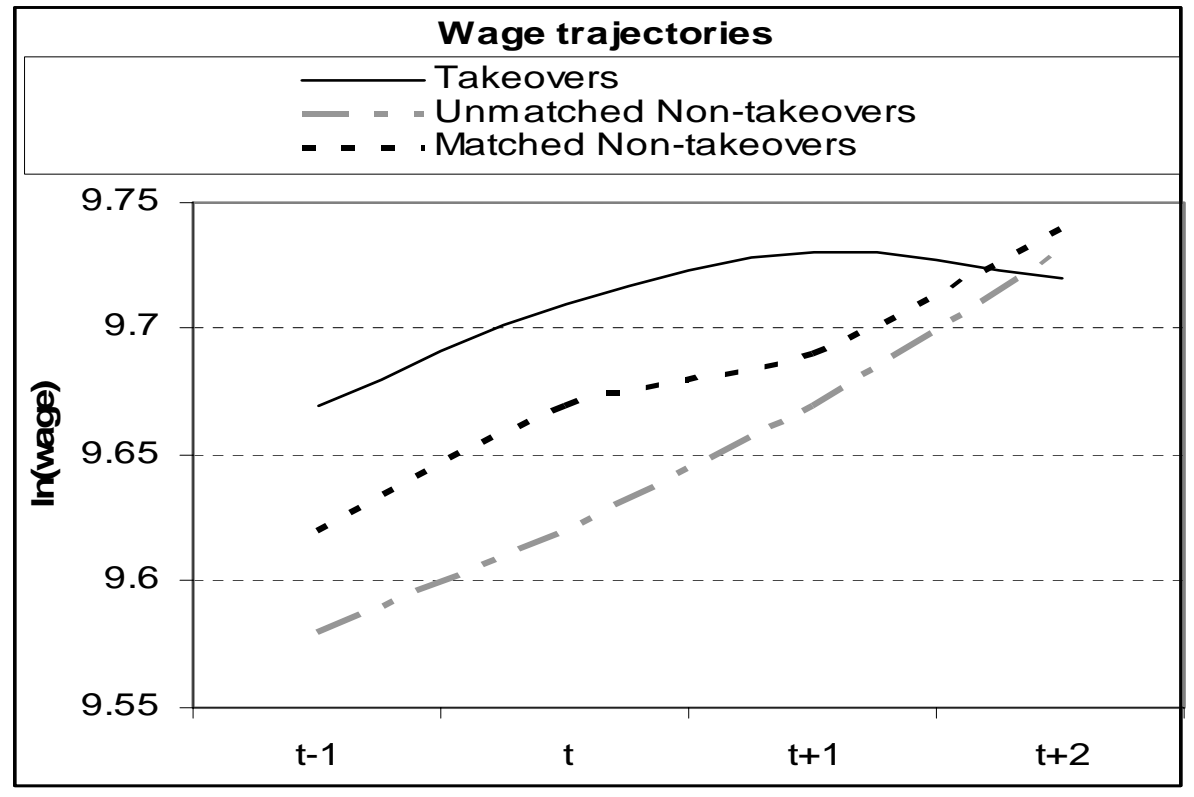


Table 6. Wage effects of foreign takeovers of Swedish firms - difference in difference estimations on the matched sample 1996-2000 (dependent variable - log monthly wage).

\begin{tabular}{|c|c|c|c|c|c|c|}
\hline & 1 & 2 & 3 & 4 & 5 & 6 \\
\hline & \multicolumn{3}{|c|}{$(\mathrm{t}+1)-(\mathrm{t}-1)$} & \multicolumn{3}{|c|}{$(\mathrm{t}+2)-(\mathrm{t}-1)$} \\
\hline Foreign takover $\mathrm{t}_{t+1}$ & $\begin{array}{l}-0.02 \\
(0.00)^{* * *}\end{array}$ & $\begin{array}{l}-0.02 \\
(0.00)^{* * *}\end{array}$ & $\begin{array}{l}-0.01 \\
(0.00)^{* * *}\end{array}$ & & & \\
\hline Foreign takeover $_{t+2}$ & & & & $\begin{array}{l}-0.08 \\
(0.00)^{* * *}\end{array}$ & $\begin{array}{l}-0.07 \\
(0.00) * * *\end{array}$ & $\begin{array}{l}-0.06 \\
(0.00) * * *\end{array}$ \\
\hline Foreign & $\begin{array}{l}0.06 \\
(0.00)^{* * *}\end{array}$ & $\begin{array}{l}0.02 \\
(0.00) * * *\end{array}$ & $\begin{array}{l}0.03 \\
(0.00) * * *\end{array}$ & $\begin{array}{l}0.06 \\
(0.00)^{* * *}\end{array}$ & $\begin{array}{l}0.02 \\
(0.00)^{* * *}\end{array}$ & $\begin{array}{l}0.03 \\
(0.00)^{* * *}\end{array}$ \\
\hline Female & -- & $\begin{array}{l}-0.13 \\
(0.00)^{* * *}\end{array}$ & $\begin{array}{l}-0.14 \\
(0.00)^{* * *}\end{array}$ & -- & $\begin{array}{l}-0.12 \\
(0.00)^{* * *}\end{array}$ & $\begin{array}{l}-0.12 \\
(0.00)^{* * *}\end{array}$ \\
\hline Education dummies & -- & included & included & -- & included & included \\
\hline Experience & -- & $\begin{array}{l}0.02 \\
(0.00)^{* * *}\end{array}$ & $\begin{array}{l}0.02 \\
(0.00)^{* * *}\end{array}$ & -- & $\begin{array}{l}0.01 \\
(0.00)^{* * *}\end{array}$ & $\begin{array}{l}0.01 \\
(0.00)^{* * *}\end{array}$ \\
\hline Experience $^{2}$ & -- & $\begin{array}{l}-0.00 \\
(0.00)^{* * *}\end{array}$ & $\begin{array}{l}-0.00 \\
(0.00)^{* * *}\end{array}$ & -- & $\begin{array}{l}-0.00 \\
(0.00)^{* * *}\end{array}$ & $\begin{array}{l}-0.00 \\
(0.00)^{* * *}\end{array}$ \\
\hline Blue-collar & -- & $\begin{array}{l}-0.09 \\
(0.00)^{* * *}\end{array}$ & $\begin{array}{l}-0.08 \\
(0.00)^{* * *}\end{array}$ & -- & $\begin{array}{l}-0.10 \\
(0.00)^{* * *}\end{array}$ & $\begin{array}{l}-0.10 \\
(0.00)^{* * *}\end{array}$ \\
\hline Log Firm size & -- & -- & $\begin{array}{l}0.03 \\
(0.00) * * *\end{array}$ & -- & -- & $\begin{array}{l}0.03 \\
(0.00)^{* * *}\end{array}$ \\
\hline Profits/Employee & -- & -- & $\begin{array}{l}0.00 \\
(0.00)\end{array}$ & -- & -- & $\begin{array}{l}0.00 \\
(0.00)\end{array}$ \\
\hline High skilled & -- & -- & $\begin{array}{l}0.01 \\
(0.00) * * *\end{array}$ & -- & -- & $\begin{array}{l}0.01 \\
(0.00) * * *\end{array}$ \\
\hline Low skilled & -- & -- & $\begin{array}{l}0.00 \\
(0.00) * * *\end{array}$ & -- & -- & $\begin{array}{l}0.00 \\
(0.00)^{* * *}\end{array}$ \\
\hline Capital intensity & -- & -- & $\begin{array}{l}0.01 \\
(0.00) * * *\end{array}$ & -- & -- & $\begin{array}{l}0.01 \\
(0.00)^{* * *}\end{array}$ \\
\hline Time trend & $\begin{array}{l}0.08 \\
(0.00) * * *\end{array}$ & $\begin{array}{l}0.07 \\
(0.00)^{* * *}\end{array}$ & $\begin{array}{l}0.06 \\
(0.00)^{* * *}\end{array}$ & $\begin{array}{l}0.13 \\
(0.00) * * *\end{array}$ & $\begin{array}{l}0.07 \\
(0.00)^{* * *}\end{array}$ & $\begin{array}{l}0.10 \\
(0.00)^{* * *}\end{array}$ \\
\hline Industry dummies & -- & included & included & -- & included & included \\
\hline R-square & 0.03 & 0.33 & 0.36 & 0.04 & 0.34 & 0.36 \\
\hline No. of observations & 49,270 & 49,014 & 49,014 & 49,270 & 48,999 & 48,999 \\
\hline
\end{tabular}

Note: Robust standard errors within brackets. * - significant at a ten percent level; ** - significant at a five percent level; *** - significant at a one percent level. Industry dummies correspond to 14 industries. $(\mathrm{t}+1)-(\mathrm{t}-1)$ refers to the difference between one year after foreign takeover compared to one year prior to takeover. $(\mathrm{t}+2)-(\mathrm{t}-1)$ corresponds to the effect two years after foreign takeover. 


\section{Appendix}

Table A1. Variables.

\begin{tabular}{|c|c|c|}
\hline \multicolumn{3}{|l|}{ Firm variables } \\
\hline Wage & $\begin{array}{l}\text { Average wage compensation per employee, including } \\
\text { payroll tax. } 1990 \text { years prices. }\end{array}$ & FS \\
\hline Profits & Profit, net of financial deduction, 1990 year prices. & FS \\
\hline Capital Intensity & Capital stock per employee, 1990 year prices. & FS \\
\hline Export share & $($ Export/sales) $* 100$ & FS \\
\hline Labor productivity & Deflated value added per employee, 1990 year prices & FS \\
\hline High Skilled & $\begin{array}{l}\text { Share of labor force with at least } 3 \text { years post- } \\
\text { secondary education. }\end{array}$ & RAMS \\
\hline Medium skilled & $\begin{array}{l}\text { Share of labor force with 1-2 years of post secondary } \\
\text { education. }\end{array}$ & RAMS \\
\hline Low Skilled & $\begin{array}{l}\text { Share of labor force with at most } 9 \text { years elementary } \\
\text { education. }\end{array}$ & RAMS \\
\hline Foreign ownership & $\begin{array}{l}\text { Dummy }=1 \text { if more than } 50 \text { percent of a firm's votes } \\
\text { is foreign owned. }\end{array}$ & FS \\
\hline Size & Number of employees & FS \\
\hline Female-share & Share of female employees & RAMS \\
\hline
\end{tabular}

Individual variables

Wage

Full time equivalent monthly wage per employee, LS 1990 year prices.

Female

Dummy $=1$ if female

LS

Dummy $=1$ if blue-collar worker

LS

Education dummies

Based on the Swedish education nomenclature

LS (SUN-codes).

(1). Elementary school $<9$ years

(2). Compulsory school $=9$ years

(3). Upper secondary, 2 years

(4). Upper secondary, 3 years

(5). Upper secondary, 4 years

(6). Undergraduate studies, 3 years

(7). $\mathrm{PhD}$.

Experience

Age minus number of years of schooling.

Other variables

Herfindahl index

$$
H_{m t}=\left\{\sum_{i=1}^{N} s_{i t}^{2}\right\}, \text { where } s_{i t}=\frac{\text { sales }_{i t}}{\sum_{i=1}^{N} \text { sales }_{i t}}
$$


Table A2. Descriptive statistics. Individual and firm characteristics.

\begin{tabular}{|c|c|c|c|c|}
\hline & \multicolumn{2}{|c|}{ Domestic firms } & \multicolumn{2}{|c|}{$\begin{array}{l}\text { Foreign } \\
\text { firms }\end{array}$} \\
\hline & Mean & SD & Mean & $\mathrm{SD}$ \\
\hline \multicolumn{5}{|l|}{ Individuals 1996-2000 } \\
\hline Log monthly wage & 9.66 & 0.28 & 9.70 & 0.30 \\
\hline Female & 0.36 & 0.48 & 0.30 & 0.46 \\
\hline Experience & 32 & 11 & 32 & 11 \\
\hline \multicolumn{5}{|l|}{ Education level: } \\
\hline Elementary School <9 & 0.10 & 0.85 & 0.12 & 1.58 \\
\hline Compulsory School =9 & 0.12 & 1.04 & 0.14 & 1.42 \\
\hline Upper Secondary School $<3$ & 0.39 & 1.43 & 0.33 & 3.12 \\
\hline Upper Secondary School =3 & 0.17 & 0.37 & 0.18 & 0.38 \\
\hline Upper Secondary School $=4$ & 0.13 & 0.34 & 0.12 & 0.33 \\
\hline University undergraduate & 0.09 & 0.28 & 0.09 & 0.29 \\
\hline University graduate & 0.01 & 0.07 & 0.01 & 0.09 \\
\hline Blue collar & 0.41 & 0.49 & 0.51 & 0.50 \\
\hline Number of observations & \multicolumn{2}{|c|}{$1,317,275$} & \multicolumn{2}{|c|}{296,897} \\
\hline \multicolumn{5}{|l|}{ Firms 1990-2000 } \\
\hline Profits/Employee & 111.5 & 2651 & 101.8 & 448 \\
\hline High skilled & 5.82 & 11.2 & 10.5 & 12.0 \\
\hline Medium skilled & 53.6 & 14.4 & 51.1 & 12.7 \\
\hline Low skilled & 30.3 & 16.2 & 22.6 & 14.4 \\
\hline Female share & 0.30 & 0.24 & 0.31 & 0.18 \\
\hline Log firm size & 4.10 & 0.96 & 4.64 & 1.07 \\
\hline Export share & 7.56 & 20.0 & 20.81 & 29.5 \\
\hline Labor productivity & 1471 & 2610 & 2449 & 3860 \\
\hline Number of observations & \multicolumn{2}{|c|}{53587} & \multicolumn{2}{|c|}{7979} \\
\hline
\end{tabular}

Table A3. Propensity Score matching. 1:st step logit model. Dependent variable is Foreign ownership.

\begin{tabular}{lll} 
& 1997 & 1998 \\
\hline & & \\
Log investments over sales & -0.04 & 0.00 \\
& $(0.05)$ & $(0.02)$ \\
Log labor productivity & -1.02 & -0.09 \\
& $(0.72)$ & $(0.52)$ \\
Profits/sales & 0.00 & 0.02 \\
& $(0.00)$ & $(0.01)$ \\
Log firm size & 0.19 & 12.3 \\
& $(0.22)$ & $(12.86)$ \\
Log firm age & 0.67 & $-0.51^{*}$ \\
& $(0.56)$ & $(0.31)$ \\
\hline
\end{tabular}




\begin{tabular}{lll}
\hline Log capital per employee & $1.22 * * *$ & $0.17 * * *$ \\
& $(0.46)$ & $(0.26)$ \\
High skilled & 0.02 & -0.01 \\
& $(0.06)$ & $(0.04)$ \\
Mean wage & -1.16 & -2.61 \\
& $(1.95)$ & $(1.83)$ \\
Export share & $0.03 * *$ & $0.02 *$ \\
& $(0.01)$ & $(0.01)$ \\
& & \\
Industry dummies & included & included \\
Number of observations & 466 & 710 \\
Pseudo R & 0.22 & 0.28 \\
\hline
\end{tabular}

Note: Robust standard errors within brackets. * - significant at a 10 percent level; ** - significant at a five percent level; $* * *$ - significant at a one percent level. All explanatory variables are lagged one year. The 1997 specification also include share of medium skilled employees, while for 1998 we also included (Profits/sales) $)^{2},(\log \text { firm size })^{3}$ and $(\log \text { firm size })^{2}$. See Section III for information on how the matching procedure was implemented. 